would lead to inflammation or even suppuration of the sac. This was the common opinion when such coagulation was produced by various direct methods of treatment-manipulation, injection, passage of foreign bodies into the sac,which it is evident were highly likely to lead to such a result. But it is very difficult to understand how a simple blood-clot can do it.

I was not able to examine the specimen this evening until it was too late to join in the discussion at the Pathological Society, and this is my excuse for troubling you with these remarks.

I am, Sir, your obedient servant,

Gower-street, Nor. 6th, 1877 .

$$
\text { A. Pearce Gould, M.S., F.R.C.S. }
$$

\section{THE HOSPITAL FOR DISEASES OF THE THROAT.}

To the Editor of THe Lavcet.

SIR,-I am astonished beyond measure that you should blame the silence of the staff of the Throat Hospital, when you have had, as I am informed, their formally expressed opinion in your own possession for more than three months. The confusion attending a recent change of residence prevents me from referring to the numbers of THE LANCET which have appeared since their resolution was adopted, but a friend who has watched them declares you have not published it. How, then, can you blame the staff for maintaining silence? They cannot compel you to publish their resolutions.

Having pen in hand, it may be as well to dispose of another point in your article. You say the " report" of the so-called "committee of inquiry is still withheld." Surely, it is not the business of the staff to publish that. How can they? They have no knowledge of it. If the so-called "committee" have agreed upon a "report," but have not the courage to publish it, how can the staff help them out of their false position? Do you think the staff ought to circulate allegations which they consider either unfounded or frivolous.

And, after all, what is this committee of inquiry? Certain individuals appear to have held a private meeting to liston to the allegations of dissatisfied officials who had resigned or been dismissed. They did not inspect the several departments of the hospital, they did not communicate with the members of the staff, nor have they furnished them with their "report," if indeed they have agreed upon it. If laymen thus presume to pronounce on hospital work the staff can afford to smile at their self-complacency. It resembles that of the noblemen and gentlemen who, from their innate knowledge of therapeutics, are able to testify to the wonderful virtues of quack medicines. If medical men without examination attempt in the same way to disparage the work of their professional brethren, it is to their conduct your editorial attention should be directed. I think the staff can afford to ignore such an "inquiry," but as you assert that " it is incumbent upon them either to admit or disprove the charges that have been made," I am induced to protest against any such conclusion, especially as I am only just resuming practice after a lengthened illness, during which the transactions took place.

My clinic was always open to any medical man, and I would not for a moment shirk my responsibility for its conduct. Those who bave not inspected it can have no right to pronounce an opinion upon it. Any attempt to involve the whole staff in a private dispute is quite unwarrantable. I am, Sir, your obedient servant,

Dean-street, Park-lane, November 6th. Prosser JAMrms.

** If Dr. Prosser James will refer to an annotation in The Lancet of Oct. $20 \mathrm{th}$, pp. 589 and 590 , he will find this sentence:- "It is only right to add that since the above inquiry the other members of the medical staff have passed a vote of confidence in the medical superintendent, and have expressed their opinion that the charges brought against him are unfounded." We did not publish the "formally expressed opinion" to which our correspondent alludes, because it was a curt repudiation of certain charges not detailed. The public duty which, we repeat, the medical and surgical staff of this hospital have so strangely neglected is that of meeting the specific charges boldly, taking the profession into their confidence, and disproving the allegations made. Instead of this course being adopted the proceedings seem to be ensbrouded in needless obscurity, and the full facts have not transpired. It may not, finally, be incumbent on persons accused of neglect or mismanagement to publish the case against them, but it would be eimply obeying the natural impulse of a keen Eense of honour to repudiate in public the imputation privately made, but, if rumour may be trusted, relating to the manner in which a public duty has been dischargedED. L.

\section{ARTICULAR RHEUMATISM.}

To the Editor of THE LANCET.

SrR,-Will you permit me to say, with reference to some remarks in THE LANCET of Nov. 3rd, that I do not think we have sufficient evidence to admit of dividing articular rheu. matism into the two forms suggested. The records of Charing-cross Hospital for the past year tend to show that subacute cases of rheumatism-cases in which the temperature has never exceeded $100^{\circ} \mathrm{Fahr}$. - are quite as eligible for treatment by salicylate of soda as the more acute forms; and, further, I venture to assert, what I believe time will prove, that there is no form of true articular rheumatism, except the malignant, that will not be more or less benefited by the administration of salicylate of soda in appropriate doses.

I remain, Sir, your obedient servant,

Harley-street, Nov. 6th, 1877. Julius Poliock.

\section{THE UNIVERSITY OF MELBOURNE.}

To the Editor of THE LANCET.

SIR,-I have the honour to address you on a subject which concerns the interests of the medical graduates of this University. In Tre Lancet of June 2nd, 1877, I find the following paragraph:- "The project of registering colonial degrees involves the question of reciprocity. The colonies re-examine men holding British qualifications before they are admitted to practise in those outlying provinces of Her Majesty's dominions."

Permit me to inform you that the latter statement is certainly incorrect as regards this colony, in which all men possessing British qualifications are free to practise immediately after their arrival without any re-examination, having only to present their diplomas to the Medical Board of Victoria for registration.

As it would be a great disappointment to our graduates if any further delay should be caused in the prompt registra. tion of their degrees by a wrong impression being made on the home authorities by such statements as the one I have referred to, I trust that you will be good enough to give publicity to this letter in your valuable and influential journal.

\section{I am, Sir, our most obedient servant, A. C. Brownless, M.D.} Vice-Chancellor of the University of Melbourne.

\section{(10bituatr.}

\section{FRANCIS AUGUSTUS BURDETT BONNEY.}

Mr. BoNNEY, who died at his residence, Elm House, on the 13th ult., aged serenty-three, was the son of John Augustus Bonney, a solicitor, of good family, who, as the friend of Horne Tooke, became involved in the State prosecutions of the year 1794. Born in London in 1804, the subject of this memoir was educated at Ealing School. During the interval which afterwards elapsed before his final choice of a profession, made difficult by the early death of his father, he supplied many contributions, 